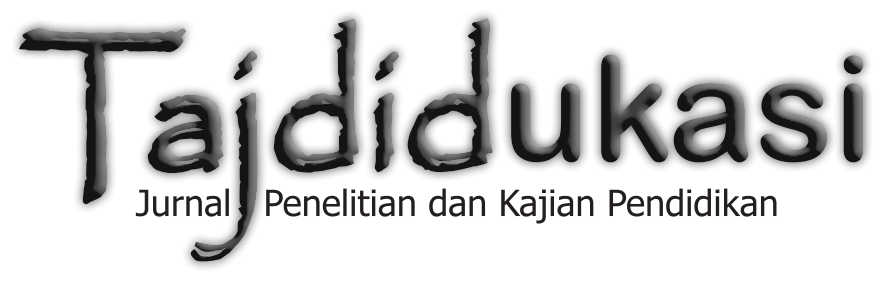




\section{Tajdidukasi}

Volume VIII, No. 1, Januari 2018

ISSN: 1979-6943

Tajdidukasi: Jurnal Penelitian dan Kajian Pendidikan merupakan jurnal Penelitian dan Kajian Pendidikan yang berisi Penelitian Tindakan Kelas (PTK) dan Penelitian Tindakan Sekolah (PTS) serta Kajian Pendidikan interdisipliner di Perguruan Tinggi yang diterbitkan Majelis Pendidikan Dasar dan Menengah Pimpinan Wilayah Muhammadiyah Daerah Istimewa Yogyakarta. Artikel hasil PTK dan PTS serta kajian pemikiran pendidikan ditulis oleh para Guru dan Kepala Sekolah serta Dosen dalam mengujicobakan metode dan strategi pembelajaran untuk meningkatkan kualitas pendidikan baik SD/MI, SMP/MTs dan SMA/MA/SMK serta Perguruan Tinggi. Artikel PTK dan PTS fokus pada mata pelajaran di sekolah/madrasah, seperti Ilmu Pengetahuan Alam (IPA), Imu Pengetahuan Sosial (IPS), Matematika, Fisika, Kimia, bahkan teknik, seperti Teknik Mesin, Elektro, Informatika dan lain sebagainya. Sementara itu, artikel Kajian Pendidikan merupakan penelitian interdisipliner dan multidisipliner yang dilakukan Dosen di Perguruan Tinggi terhadap khasanah keIslaman.

Tajdidukasi: Jurnal Penelitian dan Kajian Pendidikan adalah jurnal terbuka yang versi softfile-nya bisa dibaca dan diakses secara gratis, sementara versi print out/ hardcopy dapat diperoleh dengan menghubungi distributor di alamat serial tajdidukasi.ac.id. Sof-file keseluruhan artikel yang diterbitkan dapat diakses melalui Tajdidukasi Open Access Juornal di www.dikdasmenpwmdiy.or.id

\section{Pimpinan Editor \\ Suyadi, Universitas Ahmad Dahlan (UAD) Yogyakarta, Indonesia}

\section{Anggota Editor}

Arif Budi Raharjo, Universitas Muhammadiyah Yogyakarta (UMY), Indonesia

Achmad Muhammad, UIN Sunan Kalijaga Yogyakarta, Indonesia

Hendro Widodo, Universitas Ahmad Dahlan (UAD) Yogyakarta

Mundzirin Yusuf, UIN Sunan Kalijaga Yogyakarta, Indonesia

Sumedi, UIN Sunan Kalijaga Yogyakarta, Indonesia

Sukamto, Universitas Muhammadiyah Yogyakarta (UMY), Indonesia

Sumarsono, UIN Sunan Kalijaga Yogyakarta Indonesia

Sarjilah (Lembaga Penjaminan Mutu Pendidikan) Yogyakarta

Fathur Rahman, M.Si., Universitas Negeri Yogyakarta (UNY) Indonesia

\section{Editor Pelaksana}

Suryanto, Universitas Muhammadiyah Yogyakarta (UMY), Indonesia

Suyatno, Universitas Ahmad Dahlan (UAD) Yogyakarta

Farid Setiawan, Universitas Ahmad Dahlan (UAD) Yogyakarta

Alamat Redaksi:

Kantor Majelis Pendidikan Dasar dan Menengah Pimpinan

Wilayah Muhammadiyah D.I. Yogyakarta

Jl. Gedongkuning No. 130B Yogyakarta

Kode Pos : 55171

Telephone : (0274) 377078

Facsimile : (0274) 371718

Website : www.dikdasmenpwmdiy.or.id

E-Mail : tajdidukasi@dikdasmenpwmdiy.or.id 


\title{
PENGEMBANGAN SUMBER DAYA MANUSIA DI LEMBAGA PENDIDIKAN ISLAM
}

\author{
Djamaluddin Perawironegoro \\ Universitas Ahmad dahlan \\ djamaluddin@mpai.uad.ac.id
}

\begin{abstract}
Abstrak
Sampai saat ini, manusia masih menjadi media yang paling efektif dalam proses internalisasi nilai-nilai pendidikan kepada peserta didik. Oleh karena keefektifan tersebut, pengetahuan, skill, dan sikap yang dimiliki oleh para pendidik dapat dikembangkan agar tujuan pendidikan yang diharapkan terwujud sesuai sasaran. Paper ini bertujuan untuk mendeskripsikan urgensi kegiatan pengembangan sumber daya manusia di lembaga pendidikan Islam. Berdasarkan hasil kajian yang telah dilakukan, disimpulkan bahwa pengembangan sumber daya manusia di sekolah/madrasah Islam merupakan suatu kebutuhan untuk mencapai tujuan yang diharapkan. Pengembangan tersebut adalah pengembangan profesionalisme dan profesionalitas. Adapun kegiatan tersebut dilakukan melalui pembelajaran, pendidikan, pengembangan, dan pelatihan.
\end{abstract}

Kata Kunci: Pengembangan SDM, Profesionalisme, Profesionalitas

\section{A. Pendahuluan}

Sumber daya manusia dalam lembaga pendidikan merupakan salah satu sub sistem manajemen yang perlu mendapat perhatian yang sama dengan sub sistem manajemen yang lain, karena merupakan kunci keberhasilan pendidikan (Pidarta, 2011; 113). Kelengkapan sarana dan prasarana, ketersidaan dana, dan dukungan dari berbagai lembaga dan departemen, tidak memberikan jaminan akan ketercapaian tujuan pendidikan, jika tidak didukung oleh para tenaga pendidik dan kependidikan di lingkup sekolah/madrasah.

Kritik atas pendidikan di Indone- sia, disampaikan oleh Tilaar (2008; 140-141) yang pada substansinya adalah fokus pendidikan masih tertuju pada kuantitas daripada kualitas, dan pendidikan berkualitas merupakan konsumsi kaum elit. Kritik ini dapat dibuktikan pada beberapa sekolah di sekitar kita, yang cenderung terobsesi untuk meningkatkan jumlah peserta didik berikut mengembangkan sarana dan prasarana yang memadai, dengan biaya sekolah yang tinggi. Akan tetapi dalam perkembangan kuantitas dan pengembanan sarana-prasarana tidak diimbangi dengan peningkatan sumber daya manusia yang ada di sekolah. 
Berdasarkan data yang dirilis oleh UNDP, Indeks Pembangunan Manusia (IPM) atau dalam istilah lain disebut Human Development Index (HDI), pada tahun 2013 Indonesia berada pada posisi 108 diantara 187 negara, dengan nilai 0,684 . Dengan perhitungan klasifikasi IPM adalah sebagai berikut; 1) pembangunan manusia sangat tinggi yaitu Negara maju 0,900 - 1000;2) pembangunan manusia tinggi Negara berkembang $0,800-0,899$; 3) pembangunan manusia menengah Negara berkembang $0,500-0,799 ; 4$ ) pembangunan manusia rendah $0,000-0,499$. Maka Indonesia masuk dalam kategori negara dengan pembangunan manusia menengah negara berkembang.

Pencapaian nilai Programme for International Student Assesment (PISA). PISA merupakan sistem ujian untuk mengevaluasi sistem pendidikan dari 72 negara di seluruh dunia. Tes yang dilakukan mencakup tiga kompetensi dasar yaitu membaca, matematika, dan sains. Berdasarkan hasil tersebut, Indonesia berada pada peringkat ke 62, dibawahnya ada Brasil, Peru, Lebanon, Tunisia, Kosovo, Aljazair, dan Republik Dominika. Sedangkan negara-negara Eropa seperti Inggris, Jerman, Belanda, dan Swiss masing-masing berada di urutan 15, 16, 17, dan 18, berada pada posisi puncak adalah Singapura. Sing Kong Lee seorang guru besar dan wakil presiden di Nanyang Technological University mengungkapkan "Singapura banyak melakukan investasi untuk meningkatkan kualitas guru... ini untuk menaikkan prestise dan status sebagai guru”. (BBC, 7/12/2016)

Data-data tersebut menunjukkan bahwa prestasi yang telah dicapai oleh para peserta didik di Indonesia masih tertinggal jauh dibandingkan dengan negara-negara lain. Berkaca dari prestasi yang dicapai oleh Singapura, kiranya dapat menjadi pertimbangan untuk menjadi yang terbaik, perhatian hendaknya bergeser dari yang bersifat kuantitatif menuju pada sifat kualitatif. Terlebih pada kualitas para tenaga pendidik dan kependidikan.

Makalah ini hendak memberikan deskripsi tentang pengembangan sumber daya manusia di lembaga pendidikan Islam. Lembaga pendidikan Islam memiliki cakupan yang luas jika ditinjau dari formalitasnya, yaitu dari pendidikan dasar hingga pendidikan tinggi, pendidikan non-formal seperti masjid, Taman Pendidikan Al-Qur'an (TPQ), majlis-masjlis ta'lim, dan lainlain. Namun pada makalah ini, lembaga pendidikan Islam di sini dimaksudkan yaitu lembaga pendidikan dasar dan menengah pada tingkat sekolah dan madrasah.

\section{B. Kajian Teoritis}

\section{A. Sumber Daya Manusia di Lem- baga Pendidikan Islam}

Disebutkan dalam Undang-Undang SISDIKNAS Nomor 20 tahun 2003 bahwa di dalam suatu lembaga pendidikan terdiri dari dua model sumber daya manusia, yaitu tenaga pendidik dan 
tenaga kependidikan. Tenaga pendidik dimaksudkan adalah tenaga professional yang bertugas merencanakan dan melaksanakan proses pembelajaran, menilai hasil pembelajaran, melakukan pembimbingan dan pelatihan, serta melakukan penelitian dan pengabdian kepada masyarakat, terutama para pendidik di perguruan tinggi. Sedangkan tenaga kependidikan didefinisikan dengan tugas melakukan administrasi, pengelolaan, pengembangan, pengawasan, dan pelayanan teknis untuk menunjang proses pendidikan pada satuan pendidikan.

Lebih lanjut diterangkan dalam Undang-Undang Nomor 14 Tahun 2005 tentang Guru dan Dosen yang mewajibkan guru untuk memiliki kualifikasi akademik, kompetensi, sertifikat pendidik, sehat jasmani dan rohani, serta memiliki kemampuan untuk mewujudkan tujuan pendidikan nasional. Demikian itu juga diperjelas pada Peraturan Pemerintah Nomor 19 tahun 2005 tentang Standar Nasional Pendidikan. Selain kualifikasi akademik, seorang guru diharuskan memiliki kompetensi pedagogik, kompetensi kepribadian, kompetensi professional, dan kompetensi sosial. Untuk tenaga kependidikan di sekolah/madrasah terdiri dari kepala sekolah, tenaga administrasi, tenaga perpustakaan, tenaga laboratorium, dan tenaga kebersihan. Pada setiap jabatan tersebut disyaratkan adanya kualifikasi akademik, pengalaman, dan kemampuan, sebagaimana telah dirincikan dalam peraturan-peraturan menteri.
Dari informasi tersebut dapat diketahui bahwa sumber daya manusia di lembaga pendidikan memiliki dua model, yaitu tenaga pendidik dan tenaga kependidikan. Pada dua model tersebut disyaratkan kepemilikian kualifikasi yang distandarkan - dan kompetensi yang terdiri dari kompetensi pedagogik, kepribadian, profesional, sosial.

Pada kualifikasi dan kompetensi inilah kegiatan pengembangan sumber daya manusia dapat dilakukan. Terhadap pengembangan kualifikasi, dapat saja dilakukan dengan tidak membatasi pada jenjang pendidikan minimal yaitu strata 1, dapat saja ditingkatkan menjadi strata 2, dan selanjutnya. Jikalau berbasis keahlian, dapat ditingkatkan melalui kursus-kursus formal yang terpercaya dalam penyelenggaraannya. Sedangkan dalam pengembangan kompetensi, menjadi suatu kegiatan yang sangat terkait dengan kegiatan-kegiatan pendidikan dan pembelajaran di sekolah atau madrasah.

\section{B. Kekuatan Pendorong}

Tilaar $(2012 ; 65)$ menyebutkan kekuatan-kekuatan yang mengubah kehidupan manusia yaitu; demokrasi, ilmu pengetahuan dan teknologi, dan globalisasi. Dijelaskan bahwa proses demokratisasi erat kaitannya dengan semakin menonjolnya tuntutan kepada penghormatan terhadap hak asasi manusia. Dalam perubahan kehidupan dan kebudayaan terdapat ilmu pengetahuan dan teknologi yang berkembang sebagai penerapan ilmu dalam bidang 
teknik dan industri, yang demikian turut mengubah cara hidup bahkan bisa jadi pandangan hidup manusia. Terkait globalisasi terdapat empat perubahan yang mendasar yaitu gelombang perubahan dalam konstelasi politik global, saling menguatnya hubungan antar negara yang berarti semakin kuatnya saling ketergantungan, globalisasi menonjolkan pemain-pemain baru di dalam kehidupan masyarakat, yaitu aktor-aktor non pemerintan, dan lahirnya berbagai isu baru di dalam agenda hubunganhubungan internasional.

Kondisi sebagaimana disampaikan oleh Tilaar tersebut, menuntut para tenaga pendidik dan kependidikan untuk mengembangkan pengetahuan dan kemampuannya. Jones dan Walters (2008; 237-238) mengungkapkan alasan utama bagi pengembangan tersebut adalah; 1) tuntutan kurikulum; 2) tantangan demografis; 3) tuntutan metodologi; dan 4) tekanan kerja.

Berbagai kekuatan pendorong tersebut, menggerakkan para pemangku kebijakan untuk memberikan perubahan pada kurikulum yang telah diselenggarakan. Perubahan kurikulum menuntut peningkatan kecakapan tenaga pendidikan dan kependidikan, tidak terbatas pada penguatan materi pembelajaran, tetapi juga terkait dengan pengembangan metode pembelajaran - tak jarang kondisi peserta didik yang berbeda antara satu zaman dengan zaman yang lain. Seiring dengan perubahan kurikulum, juga turut memberikan tekanan pada penilaian kinerja guru. Disebabkan perubahan kurikulum yang merupakan jantung dari pendidikan, maka pada sisi lain pun terjadi perubahan, untuk tidak bersikap resisten terhadap perubahan, tidak ada jalan lain untuk tidak turut meningkatkan kapasitas diri agar tidak semakin jauh tertinggal.

\section{Pengembangan Sumber Daya Manusia di Lembaga Pendidikan Islam}

Armstrong (1999: 479) mengungkapkan bahwa pengembangan sumber daya manusia adalah berfokus pada penyediaan kesempatan pembelajaran dan pengembangan, menyelenggarakan pelatihan dan perencanaan yang terarah, pengkondisian dan evaluasi program. Demikian itu merupakan hal yang penting sebagai proses strategis yang fokus pada pertemuan antara kebutuhan individu dan perusahaan.

Aktifitas dari pengembangan SDM terdiri dari empat model kegiatan; pembelajaran, pendidikan, pengembangan, dan pelatihan. Setiap kegiatan tersebut memiliki fokus yang berbeda, sebagaimana diungkapkan oleh Bass dan Vaughan yang dikutip oleh Armstrong (1999; 480). Pembelajaran adalah suatu proses yang relatif permanen memberikan perubahan dalam prilaku sebagai hasil dari praktek atau pengalaman. Pendidikan adalah pengembangan pengetahuan, nilai, dan pemahaman yang dibutuhkan dalam seluruh aspek kehidupan daripada hanya pengetahuan atau skil yang berhubungan dengan area khusus dalam aktifitas sehari-hari. 
Pengembangan adalah pertumbuhan atau realisasi dari kemampuan dan potensi seseorang dengan modal pendidikan dan pembelajaran. Sedangkan pelatihan adalah sesuatu tindakan yang direncanakan dan dimodifikasi secara sistematis melalui even pembelajaran, program kegiatan, dan instruksi yang memungkinkan setiap individu mencapai suatu level dari pengetahuan, skill, dan kompetensi agar dapat melakukan tugasnya secara efektif.

Day sebagaimana dikutip oleh Mercer et.all $(2010 ; 113)$ mengungkapkan bahwa pengembangan profesional terdiri dari segala model pembelajaran yang alami berbasis pengalaman, yang dilakukan dengan penuh kesadaran dan perencanaan, secara langsung ataupun tidak langsung memberikan manfaat untuk individu, kelompok, atau sekolah yang berkontribusi pada kualitas pendidikan di dalam kelas. Proses ini dapat dilakukan secara mandiri atau bersama yang lain, dapat juga dengan tinjauan, koreksi, sebagai perluasan dari komitmen mereka sebagai agen perubahan pada tujuan moral dari pengajaran; dan dengan hal tersebut mereka belajar dan berkembang secara kritis terhadap pengetahuan, skill, dan kecerdasan emosional. Yang demikian itu adalah esensi untuk menjadi guru profesional yang baik dalam fikiran, perencanaan, dan praktek dengan murid, pemuda, dan kolega melalui proses fase dari kehidupan mengajar mereka.

Senada dengan hal tersebut diungkapkan oleh Evans (2002: 13) pengem- bangan guru adalah suatu proses di mana profesionalitas dan profesionalisme menjadi fokus untuk ditingkatkan. Profesionalitas di sini adalah ideologi, sikap, pengetahuan, dan epistimologi yang menjadi bagian dasar dari individu, dalam hubungannya pada praktek dari profesi yang sebagaimana mestinya, dan yang memperngaruhi praktek profesi tersebut.

Dari berbagai pendapat tersebut dapat difahami pengembangan sumber daya manusia dilakukan melalui suatu kegiatan yang perencanaan yang terstruktur dalam kegiatan pengembangan, termasuk di dalamnya adalah penyediaan kegiatan pengembangan, pelaksanaan, pengarahan, dan evaluasi yang pada tujuan akhirnya adalah meningkatkan profesionalisme dan profesionalitas. Pada pelaksanaannya dapat dilakukan melalui kegiatan-kegiatan pembelajaran, pendidikan, pengembangan, dan pelatihan.

Dalam lembaga pendidikan Islam, kegiatan pengembangan sumber daya manusia sangat terkait dengan proses pendidikan dan pembelajaran di sekolah/madrasah. Pengembangan profesi guru lebih terfokus pada peningkatan kompetensi tenaga pendidik dan kependidikan, yaitu kompetensi pedagogis, kompetensi kepriabadian, kompetensi profesional, dan kompetensi sosial.

Peningkatan kompetensi di sekolah atau madrasah idealnya dilakukan secara mandiri dan bersama-sama. Secara mandiri dilakukan dengan meningkatkan kapasitas diri melalui kegiatan pem- 
belajaran, menambah wawasan dan pengetahuan, dan bereksperimen dengan pengetahuannya tersebut. Sedangkan secara bersama-sama dilakukan dengan guru lain, kepala sekolah, pengawas, penilik, atau mungkin seorang ahli yang turut memberikan sumbangsih dalam pengembangan. Karena pada dasarnya kompetensi adalah tentang kemampuan, sedangkan kemampuan dapat dibentuk dari pengetahuan yang memadai, dibantu dengan pengalaman, kemudian diberikan feedback (umpan balik) sebagai saran untuk perbaikan.

Pengembangan sumber daya manusia di lembaga pendidikan Islam dilakukan pada pengembangan kualifikasi dan kompetensi pendidik dan tenaga kependidikan. Pada proses pengembangan tersebut dibutuhkan peran seluruh elemen sekolah atau madrasah untuk turut menciptakan lingkungan yang mendukung pengembangan tersebut. Dengan harapan harmoni lingkungan, menjadi kekuatan yang mendukung pengembangan sumber daya manusia yang diharapkan.

\section{Pembahasan}

Mulyasa $(2011 ; 61)$ mengungkapkan indikator sekolah efektif adalah pengembangan guru dan staf. Pengembangan tersebut menunjukkan usaha yang terencana dari sekolah/madrasah untuk meningkatkan kemampuan dan pengetahuan yang terbaru agar selaras dengan tujuan yang diharapkan. Seiring dengan perubahan kurikulum, perubahan tujuan pembelajaran, dan perubahan pendekatan pembelajaran, tentu skil dan keterampilan guru perlu untuk diasah dan ditingkatkan.

Dalam suatu kegiatan pengembangan, dibutuhkan pengetahuan kondisi awal untuk dikembangkan. Kriteriakriteria yang telah ditetapkan dan disepakati menjadi alat ukur untuk menentukan kinerja guru dan staf. Pengukuran yang dilakukan dengan menghadapkan standar dengan realitas di sekolah/madrasah merupakan usaha untuk mengetahui proses yang telah dilaksanakan dan tujuan yang telah tercapai. Pada prosesnya dilakukan melalui kegiatan observasi kinerja, dokumentasi penilaian, dan penyediaan umpan balik pada pegawai yang biasa disebut dengan penilaian kinerja (Daft, 2010; 326). Schuler dan Jackson (1997: 3) berpendapat fokus dari penilaian kinerja adalah untuk mengetahui tingkat produktifitas, kemampuan bekerjasama, agar lebih efektif pada masa yang akan datang, sehingga dapat memberikan manfaat bagi para karyawan, organisasi - sekolah/madrasah - dan masyarakat.

Bahan-bahan tersebut menjadi temuan, yang kemudian dianalisa untuk diperbaiki agar menjadi lebih baik di masa yang akan datang. Pada proses perbaikan itulah terdapat pengembangan sumber daya manusia. Sebagaimana diungkapkan Armstrong (1999: 479) yaitu melalui penyediaan kesempatan pembelajaran dan pengembangan, menyelenggarakan pelatihan dan perencanaan yang terarah, pengkondisian dan evaluasi program. Demikian itu 
merupakan hal yang penting sebagai proses strategis yang fokus pada pertemuan antara kebutuhan individu dengan lembaga pendidikan.

Sebagaimana diungkapkan Day, pengembangan profesi di sekolah/madrasah diselenggarakan dengan model pembelajaran secara alami berbasis pengalaman yang dilakukan secara sadar - terencana - atau tidak sadar yang memberikan manfaat bagi individu dan sekolah dalam rangka peningkatan efektifitas pencapaian tujuan sekolah/ madrasah.

Menjadi fokus pengembangan profesi tenaga pendidik dan kependidikan adalah pada pengembangan kompetensi pedagogik, kompentensi kepribadian, kompetensi profesional, dan kompetensi sosial. Kompetensi di sini dimaksudkan kemampuan yang harus dimiliki oleh seorang guru agar ia dapat melaksanakan tugas mengajarnya dengan berhasil (Uno, 2007; 18).

Selain empat kompetensi tersebut, Evans (2002) menyampaikan dimensi dari pengembangan profesi guru mencakup pada pengembangan sikap, pengembangan fungsi, pengembangan aturan, dan pengembangan budaya. Dalam dimensi sikap mencakup pengembangan intelektual dan motivasi, dengan maksud bahwa dengan berkembangnya individu pada aspek intelektual akan turut meningkatkan motivasi guru. Sedangkan dalam dimensi pengembangan fungsi mencakup perubahan prosedur dan peningkatan produktifitas. Pengembangan aturan dimaksudkan sebagai suatu proses yang terdiri dari kriteria, aturan, dan tanggungjawab masih memungkinkan untuk didefinisikan ulang atau dimodifikasi. Dan pengembangan budaya sebagai suatu proses di mana budaya profesionalisme guru didefinisikan ulang atau dimodifikasi.

Berbagai ungkapan para ahli tersebut menunjukkan satu bagian dari pencapaian tujuan pendidikan mutlak diperlukan pengembangan tenaga pendidik dan tenaga kependidikan. Pengembangan tersebut terkait erat dengan pengembangan profesionalisme dan profesionalitas guru. Pengembangan profesionalisme adalah pengembangan guru pada kompetensi-kompetensi yang mencakup empat kompetensi dasar sebagai pendidik. Di dalam empat kompetensi tersebut terdapat dimensi-dimensi sikap - pengetahuan dan motivasi, fungsi - prosedur dan produktifitas, redefinisi aturan, dan modifikasi budaya.

Beberapa kasus peranan pengembangan profesi guru disampaikan oleh Al-Qahtani (2015) dalam penelitian yang dilakukan terhadap guru bahasa Inggris ditemukan bahwa pengembangan profesi guru meningkatkan cara belajar guru, dan mengembangkan kualitas pengajaran. Sebagai hasilnya adalah peningkatan prestasi dan kesuksesan murid. Tanang dan Abu (2014) dari hasil kajiannya menunjukkan bahwa pengembangan profesi guru turut memberikan masukan bagi peningkatan profesionalisme guru. Yasin (2011) pada penelitian yang dilakukan terhadap guru di madrasah ibtidaiyah negeri 
Malang dalam aspek pengembangan kompetensi pedagogik berimplikasi pada peningkatan kualitas pembelajaran. Indikator dari peningkatan tersebut adalah perbaikan proses pembelajaran dan perbaikan mutu guru yang berdampak pada peningkatan prestasi dan hasil belajar murid.

\section{Kesimpulan}

Pengembangan sumber daya manusia di lembaga pendidikan Islam menjadi suatu kebutuhan di tengah masyarakat yang bergerak dengan sangat dinamis. Hal-hal yang mendorong untuk pengembangan tesebut adalah faktor-faktor terkait gelombang demokrasi, perkembangan ilmu pengetahuan dan teknologi, dan globalisasi. Faktorfaktor tersebut mendorong untuk membuat perubahan pada aspek pemangku kebijakan - perumusan undang-undang, kurikulum, metode pengajaran dan pembelajaran, dan tekanan kerja.

Pengembangan tenaga pendidik dan kependidikan hakikatnya adalah pengembangan profesionalisme. Dimensi dari profesionalisme memuat kompetensi-kompetensi yang harus ditingkatkan, baik itu kompetensi pedagogis, pribadi, sosial, dan profesional. Dalam kompetensi-kompetensi tersebut memuat pengetahuan, motivasi, prosedur, dan produktifitas.

Pada prosesnya dilakukan melalui individu-individu atau juga dilakukan secara bersama-sama. Tindakan ini menunjukkan komitmen terhadap profesi yang menjadi jalan hidup guru dan tenaga kependidikan. Kegiatan pengembangan ini dapat dilakukan dalam bentuk-bentuk pembelajaran, pendidikan, pengembangan, dan pelatihan.

\section{E. Rujukan}

Al-Qahtani, Hind M. (2015). Teachers' Voice: A Needs Analysis of Teachers' Needs for Professional Development with the Emergence of the Current English Textbooks. English Language Teaching, Vol. 8, No. 8.

Armstrong, Michael. (1999). A Handbook of Human Resource Management Practice, London: Kogan Page Limited.

Daft, Richard L. Management. USA: South Western, 2010

Evans, Linda. (2002). What is Teacher Development? Oxford Review of Education, Vol. 28, No. 1.

Jones, James J. and Donald L. Walters, (2008). Human Resource Management in Education. Yogyakarta: Q-Media.

Mercer, Justine. Bernard Barker, and Richard Bird. (2010). Human Resource Management in Education: Context, Themes, and Impact, Abingdon UK; Routledge.

Mulyasa, E. (2011). Manajemen dan Kepemimpinan Kepala Sekolah, Jakarta: Bumi Aksara.

Schuler, Randall S. dan Susan E. Jackson. (1997). Manajemen Sumber 
Daya Manusia; Menghadapi Abad $\mathrm{Ke}$-21. Jakarta: Erlangga.

Tanang, Hasan. dan Baharin Abu. (2014). Teacher Professionalism and Professional Development Practices in South Sulawesi, Indonesia. Journal of Curriculum and Teaching. Vol. 3, No.2.

Tilaar, H.A.R. (2012). Perubahan Sosial dan Pendidikan: Pengantar Pedagogik Transformatif untuk Indonesia, Jakarta: Rineka Cipta.

Tilaar, H.A.R. (2008) Manajemen Pendidikan Nasional: Kajian Pendidikan Masa Depan, Bandung: Remaja Rosdakarya.
Uno, Hamzah B. (2007) Profesi Kependidikan; Problema, Solusi, dan Reformasi Pendidikan di Indonesia, Jakarta: Bumi Aksara.

Yasin, Ahmad Fatah. (2011). Pengembangan Kompetensi Pedagogik Guru Pendidikan Agama Islam di Madrasah; Studi Kasus di MIN 1 Malang. Jurnal El-Qudwah, Vol. 1, No. 5. Edisi April.

Pidarta, Made. (2011). Manajemen Pendidikan Indonesia, Jakarta: Rineka Cipta. 